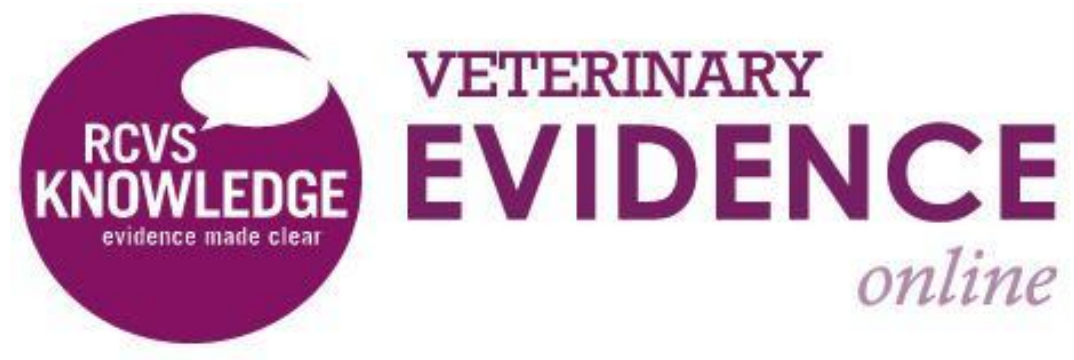

\title{
Choice of Suture Pattern for Linea Alba Closure
}

A Knowledge Summary by

Chrissy Roberts BA VetMB CertSAS MRCVS ${ }^{1 *}$

\footnotetext{
${ }^{1}$ Hale Veterinary Group, 19 Langley Road, Chippenham, Wiltshire, SN15 1BS

* Corresponding Author (chrissymaskell@yahoo.co.uk)
}

ISSN: 2396-9776

Published: 25 Sep 2017

in: Vol 2, Issue 3

DOI: http://dx.doi.org/10.18849/ve.v2i3.99

Reviewed by: Victoria Arbona (DVM, MS) and Bruce Smith

(BVSC MS FANZCVS DACVS) 


\section{Clinical bottom line}

Incidence of complications using either a simple continuous or a simple interrupted suture pattern in the linea alba is low if appropriate suture material is chosen and appropriate surgical technique is used. More, well-planned studies with higher power are required before an evidence-based recommendation for one pattern over the other can be made.

\section{Question}

In adult dogs undergoing elective midline coeliotomy, does using a simple continuous suture pattern in the linea alba affect complication rate when compared to a simple interrupted suture pattern?

\section{Clinical Scenario}

What suture pattern used for linea alba closure following elective ovariohysterectomy in the bitch will result in the lowest complication rate?

\section{The Evidence}

Canine midline coeliotomy is a commonly performed procedure in first opinion and referral small animal practice. Historically, a simple interrupted suture pattern has been employed to suture the linea alba during closure (Bellenger, 2003). Standard surgical texts also refer to a simple continuous pattern (Smeak, 2012). A simple continuous pattern has theoretical benefits over a simple interrupted pattern, taking less time and using less suture material, so it is important to know whether the two result in different complication rates, to allow veterinary surgeons to make an informed decision when choosing a pattern for linea alba closure.

Different types of study provide different strengths of evidence, as illustrated by evidence pyramids (Aragon et al., 2003). An on-line bibliographic search performed in November 2016 identified 186 possible results. A review of the results identified only five references with data relevant to answering the current question, and these sources provided only weak evidence as summarised below.

\section{Summary of the evidence}

\begin{tabular}{|c|c|}
\hline \multicolumn{2}{|l|}{ Crowe (1978) } \\
\hline Population: & $\begin{array}{l}\text { Dogs and cats ranging in age from } 4 \text { weeks to } 19 \text { years undergoing } \\
\text { midline coeliotomy for any reason at a veterinary hospital in } \\
\text { Michigan, U.S.A. over a } 2 \text { year period. }\end{array}$ \\
\hline Sample size: & 469 dogs and 81 cats, of various sizes and ages. \\
\hline Intervention details: & $\begin{array}{l}\text { The aim of the study was to provide evidence that a simple } \\
\text { continuous closure of the linea alba using non-absorbable suture } \\
\text { material is safe and effective. Following completion of the intra- } \\
\text { abdominal procedure }(\mathrm{s}) \text {, abdominal wall closure was performed } \\
\text { using polypropylene in a simple continuous pattern ( } 2 \text { metric for } \\
\text { animals }<2.5 \mathrm{~kg} \text {, } 3 \text { metric for animals } 2.5-10 \mathrm{~kg} \text { and } 3.5 \text { metric for } \\
\text { those }>10 \mathrm{~kg} \text { ). Suture bites were placed } 3-5 \mathrm{~mm} \text { from the incised }\end{array}$ \\
\hline
\end{tabular}




\begin{tabular}{|c|c|}
\hline & edge and $5-10 \mathrm{~mm}$ apart. \\
\hline Study design: & Prospective clinical case series. \\
\hline Outcome studied: & $\begin{array}{l}\text { Subjective assessment of patient comfort and the gross } \\
\text { characteristics of the healing incision, attempting to follow each } \\
\text { patient for at least two months post-operatively. }\end{array}$ \\
\hline $\begin{array}{l}\text { Main findings: } \\
\text { (relevant to PICO question): }\end{array}$ & $\begin{array}{l}\text { One abdominal wall dehiscence recognised out of } 550 \text { abdominal } \\
\text { wall closures }(0.18 \%) \text {, which occurred due to suture breakage. No } \\
\text { other wound complications attributed to the closure or suture } \\
\text { material were noted in other patients. }\end{array}$ \\
\hline Limitations: & $\begin{array}{l}\text { - No control group. } \\
\text { - } \quad \text { Number of surgeons involved and their experience not stated. } \\
65 \text { animals followed up for } 10 \text { days or less - insufficient time for } \\
\text { all possible complications to develop. } \\
\text { - } \quad \text { Precise nature of follow-up after suture removal (veterinary vs } \\
\text { owner assessment) not clear. } \\
\text { - } \quad \text { Inclusion/exclusion criteria not clearly stated - i.e. not clear if } \\
\text { every consecutive abdominal surgery within the study time } \\
\text { period (December } 1975 \text { to December 1977) was included or } \\
\text { whether some were excluded. Not clear if animals that had } \\
\text { previously had abdominal surgery were excluded or not. } \\
\text { Multiple patient and surgical variables: two species, large age } \\
\text { range, large weight range (1-80 kg), multiple indications for } \\
\text { coeliotomy, large range in length of 'abdominal incision' from 3- } \\
55 \mathrm{~cm} \text {, variation in wound classification on closure. } \\
\text { Degree of post-operative confinement not stated. }\end{array}$ \\
\hline
\end{tabular}

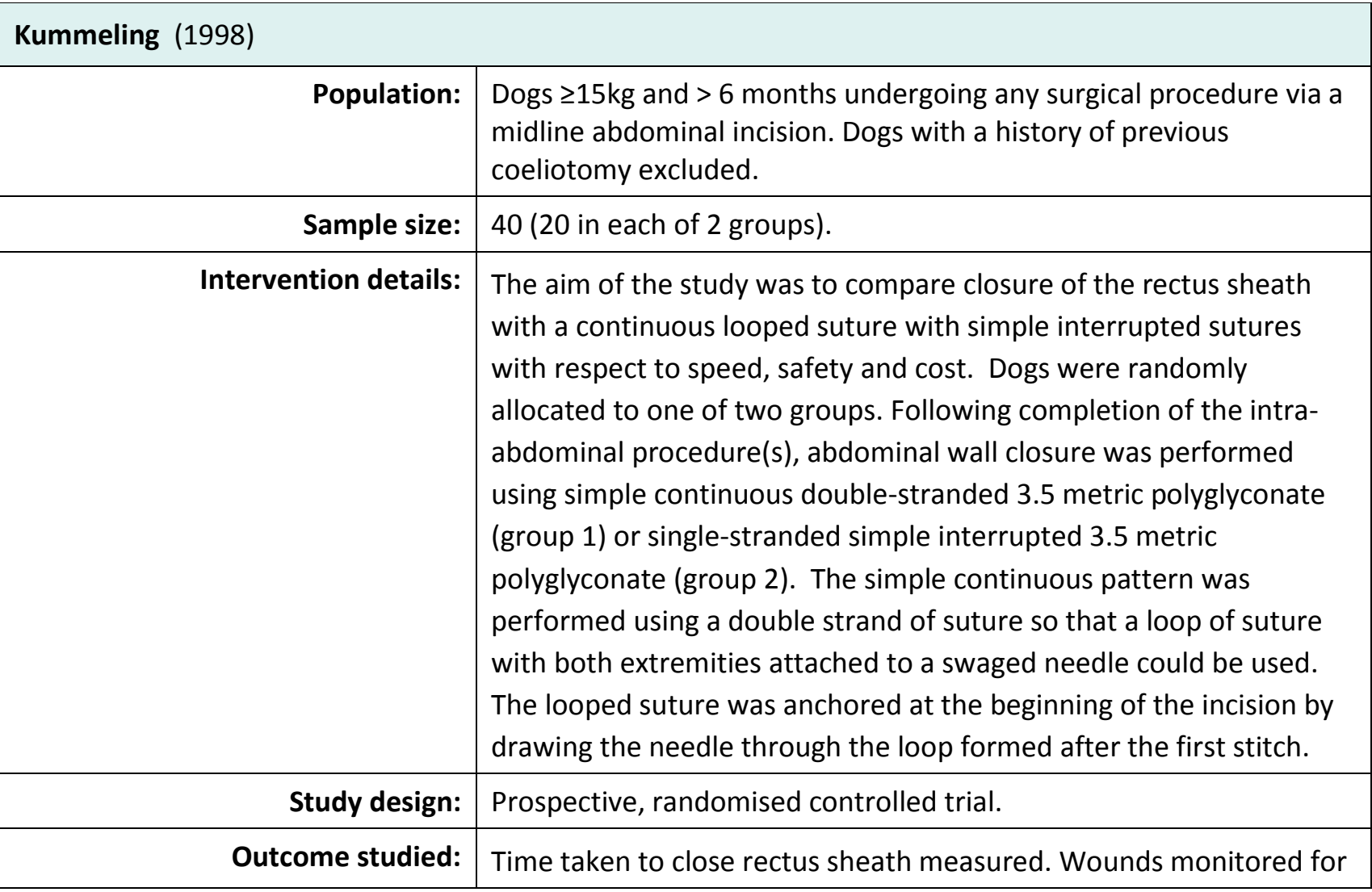




\begin{tabular}{|c|c|}
\hline & $\begin{array}{l}\text { three days after surgery. Owner assessed outcome obtained via } \\
\text { telephone call one month after surgery. }\end{array}$ \\
\hline $\begin{array}{l}\text { Main findings: } \\
\text { (relevant to PICO question): }\end{array}$ & $\begin{array}{l}\text { Dehiscence of linea alba recorded in one case }(5 \%) \text { closed with } \\
\text { simple interrupted sutures due to knot loosening. } \\
\text { Time taken to close rectus sheath significantly shorter using simple } \\
\text { continuous pattern (mean duration for rectus sheath closure was } 5.3 \\
\text { minutes using simple continuous pattern and } 8.7 \text { minutes using } \\
\text { simple interrupted pattern). Mean length of incision was } 18 \mathrm{~cm} \text { in } \\
\text { the group closed with a simple continuous pattern and } 17 \mathrm{~cm} \text { in the } \\
\text { group closed with a simple interrupted pattern. }\end{array}$ \\
\hline Limitations: & $\begin{array}{l}\text { - Power calculation not performed. } \\
\text { - } \quad \text { Follow-up duration (one month) insufficiently long for fascial } \\
\text { healing to occur. } \\
\text { - Owner assessed outcome at the one month time point. Wound } \\
\text { healing only assessed by a vet for three days post-operatively. } \\
\text { - Double strand of } 3.5 \text { metric polyglyconate used in simple } \\
\text { continuous closure vs single strand of } 3.5 \text { metric polyglyconate } \\
\text { used in simple interrupted closure. } \\
\text { - } \quad \text { Large variation in weight, age, wound classification and duration } \\
\text { of surgical procedure, although the differences in these variables } \\
\text { was not significant between groups. } \\
\text { - Variation in how the subcutaneous tissues were closed (one or } \\
\text { two layers). } \\
\text { - Nine surgeons involved, level of surgical experience not } \\
\text { recorded. } \\
\text { Degree of confinement post-operatively not } \\
\text { recorded/standardised. }\end{array}$ \\
\hline
\end{tabular}

\begin{tabular}{|c|c|}
\hline 985) & \\
\hline Population: & Dogs and cats undergoing a variety of abdominal procedures. \\
\hline Sample size: & 61 dogs and 30 cats. \\
\hline Intervention details: & $\begin{array}{l}\text { The purpose of the study was to provide evidence that a simple } \\
\text { continuous suture pattern for single layer closure of the rectus fascia } \\
\text { is a safe alternative to a simple interrupted pattern. Following } \\
\text { completion of the intra-abdominal procedure(s), abdominal wall } \\
\text { closure was performed using a simple continuous pattern. Various } \\
\text { suture materials were used (polyglycolic acid, polyglactin 910, } \\
\text { polydioxanone, polypropylene and nylon). } 2 \text { metric suture material } \\
\text { was used for cats and small dogs, } 3 \text { metric for medium dogs and } 3.5 \\
\text { metric for large dogs. Suture bites were placed 3-5mm from the } \\
\text { incised edge and 5-10mm apart. }\end{array}$ \\
\hline Study design: & Prospective clinical case series. \\
\hline Outcome studied: & $\begin{array}{l}\text { Surgical site examined at the time of removal of skin sutures } 6-12 \\
\text { days after surgery. Owner assessed outcome obtained by telephone } \\
\text { call six months after surgery. }\end{array}$ \\
\hline Main findings: & No incisional hernias recorded in the dogs. One incisional hernia \\
\hline
\end{tabular}




\begin{tabular}{|c|c|}
\hline (relevant to PICO question): & noted in a cat three weeks after surgery. \\
\hline Limitations: & $\begin{array}{l}\text { - } \quad \text { No control group. } \\
\text { - } \quad \text { Size, age, weight and body condition score of animals not } \\
\text { - } \quad \text { Duration of anaesthesia/surgery for each case not recorded. } \\
\text { - } \quad \text { Indication for surgery in each case not recorded. } \\
\text { - } \quad \text { Not clear if all incisions were median or whether some were } \\
\quad \text { paramedian. } \\
\text { - Wound classification on closure not recorded (e.g. presence or } \\
\text { absence of peritonitis). } \\
\text { - Suture material not standardised; various different suture } \\
\text { materials with different initial tensile strength and absorption } \\
\text { profiles used. } \\
\text { Time scale of veterinary follow-up (6-12 days) insufficient for } \\
\text { fascial healing to occur. }\end{array}$ \\
\hline
\end{tabular}

\begin{tabular}{|c|c|}
\hline \multicolumn{2}{|l|}{ Kirpensteijn (1993) } \\
\hline \multicolumn{2}{|c|}{ 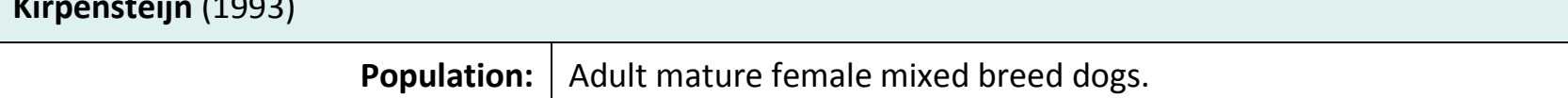 } \\
\hline Sample size: & $\begin{array}{l}18 \text { dogs in phase II (three phase study, phase II experimental trial } \\
\text { most relevant to current PICO) }\end{array}$ \\
\hline Intervention details: & $\begin{array}{l}\text { Ventral midline abdominal incision made from } 5 \mathrm{~cm} \text { cranial to } \\
\text { umbilicus and extending } 20 \mathrm{~cm} \text { caudally. Incision divided into } 4 \times 5 \mathrm{~cm} \\
\text { segments. Each segment of linea alba closed with either stainless } \\
\text { steel fascial staples or } 3.5 \mathrm{~m} \text { polypropylene in a simple continuous } \\
\text { pattern. Closure technique randomly assigned to each segment. } \\
\text { Subcutaneous tissue closed with } 3 \text { metric polyglactin } 910 \text { in a simple } \\
\text { continuous pattern. Skin apposed with } 1.5 \text { metric polyglactin } 910 \text { in } \\
\text { a simple continuous subcuticular pattern. }\end{array}$ \\
\hline Study design: & $\begin{array}{l}\text { Three phase study: } \\
\text { Phase I- experimental, cadaveric, biomechanical. } \\
\text { Phase II - experimental, randomised, controlled. Dogs were } \\
\text { randomly allocated to linea alba closure with staples or simple } \\
\text { continuous closure with polypropylene. } \\
\text { Phase III - prospective, clinical (only stainless steel staples used to } \\
\text { close the linea alba in this phase). }\end{array}$ \\
\hline Outcome studied: & $\begin{array}{l}\text { Clinical examination including abdominal incision evaluation twice } \\
\text { daily until euthanasia. Groups of six dogs each euthanised at 7, } 14 \\
\text { and } 31 \text { days (groups A, B and C respectively). Incisions examined at } \\
\text { post-mortem. Breaking strength was measured by placing tissue } \\
\text { samples in tension grips and applying load until failure. Histologic } \\
\text { appearance was assessed. }\end{array}$ \\
\hline $\begin{array}{l}\text { Main findings: } \\
\text { (relevant to PICO question): }\end{array}$ & $\begin{array}{l}\text { All group A and B dogs and one group C dog had mild seroma } \\
\text { formation in the subcutaneous tissue at post-mortem examination. } \\
\text { Omental fat was herniated between staples in group A dogs and one } \\
\text { group C dog. One group B dog had omental fat herniated in both a } \\
\text { stapled and sutured incision. No other complications reported. }\end{array}$ \\
\hline
\end{tabular}




\begin{tabular}{|c|c|}
\hline Limitations: & $\begin{array}{l}\text { - Surgical technique (e.g. distance of suture bites from incised } \\
\text { edge, distance between suture bites) not described. } \\
\text { - } \quad \text { Although } 5 \mathrm{~cm} \text { segments of linea alba were closed with a simple } \\
\text { continuous pattern, this does not fairly represent closure of a } \\
\text { whole linea alba incision with a single simple continuous suture. }\end{array}$ \\
\hline
\end{tabular}

\begin{tabular}{|c|c|}
\hline \multicolumn{2}{|l|}{ Kennedy (2011) } \\
\hline Population: & $\begin{array}{l}\text { Cats and dogs from animal shelters eligible for ovariohysterectomy } \\
\text { by third-year veterinary students at a veterinary school. Animals } \\
\text { with concurrent illness or a problem that increased risk of } \\
\text { anaesthesia/surgery were excluded. }\end{array}$ \\
\hline Sample size: & 307 cats and 206 dogs. \\
\hline Intervention details: & $\begin{array}{l}\text { The purpose of the study was to describe morbidity associated with } \\
\text { ovariohysterectomy when performed by third year veterinary } \\
\text { student as part of a surgical training programme. Animals } \\
\text { underwent ventral midline coeliotomy and ovariohysterectomy. } \\
\text { Linea alba was closed with a simple continuous pattern with } \\
\text { synthetic absorbable suture material. Each student performed two } \\
\text { surgeries. }\end{array}$ \\
\hline Study design: & Prospective clinical case series. \\
\hline Outcome studied: & $\begin{array}{l}\text { Anaesthetic time and complications, surgery time and complications, } \\
\text { post-operative complications including seroma formation, } \\
\text { abdominal wall dehiscence, incisional infection and skin incision } \\
\text { dehiscence. Animals assessed every } 8 \text { hours until discharge } 72 \text { hours } \\
\text { after surgery. }\end{array}$ \\
\hline $\begin{array}{l}\text { Main findings: } \\
\text { (relevant to PICO question): }\end{array}$ & $\begin{array}{l}\text { 7/206 dogs (3.4\%) developed major complications. The most } \\
\text { common major complication was dehiscence of the abdominal wall. } \\
19 / 206 \text { dogs ( } 9.2 \% \text { ) developed minor complications including } \\
\text { seroma formation, incisional infection or skin incision dehiscence. } \\
\text { Significantly higher number of major surgical complications } \\
\text { observed with students performing their first surgery compared to } \\
\text { those performing their second surgery. }\end{array}$ \\
\hline Limitations: & $\begin{array}{ll}\text { - } & \text { No control group. } \\
\text { - } & \text { All surgeons were students (limited prior surgical experience). } \\
\text { - } & \text { Details of surgical technique (e.g. distance of suture bite from } \\
\text { incision, distance between suture bites) not given. } \\
\text { - } \quad \text { Variation in subcutaneous tissue closure between cases. } \\
\text { - } \quad \text { Very limited follow-up duration (72 hours). } \\
\text { - } \quad \text { Number of dogs developing each specific complication not } \\
\text { recorded. }\end{array}$ \\
\hline
\end{tabular}

Appraisal, application and reflection

Only five sources with data relevant to the current question were identified. 
Two of the sources were randomised controlled trials in adult dogs (Kirpensteijn et al., 1993; Kummeling et al., 1998). Neither study design was optimal. The sample size in the experimental Kirpensteijn study was very small (18 dogs), the suture material used for the simple continuous sections of linea alba closure (polypropylene) was not a type that is commonly used in linea alba closure in the U.K., and the 'control' was sections of linea alba apposed with stainless steel staples. Kummeling (1998) used 20 dogs in each group, but a power calculation was not performed to assess whether this sample size would be sufficient to attain statistical significance given that the difference in complication rate between the two groups was likely to be small. Another criticism of the Kummeling study is that only one strand 3.5 metric polyglyconate was used for the simple interrupted linea alba closures, whereas a double strand of the same suture material was used for the simple continuous closures.

The three remaining studies were prospective case series. All three included cats as well as dogs, the feline outcomes not being relevant to the current question. One of the case series studies (Crowe, 1978) again used polypropylene suture material while in another (Rosin, 1985) a variety of suture materials and sizes were used. Rosin and Crowe gave a description of how sutures were placed (bites placed $3-10 \mathrm{~mm}$ and $3-5 \mathrm{~mm}$ from incised edge respectively, with both studies placing bites $5-10 \mathrm{~mm}$ apart). Surgical technique was not described in the third case series (Kennedy et al., 2011).

The number of surgeons involved and surgical experience was not stated in the Rosin and Crowe studies, but the Kennedy study used third year veterinary students in a surgical training programme, which is likely to have adversely affected complication rates. In all three case series studies, veterinary follow-up was of insufficient duration to allow for fascial healing. Histologic assessment of linea alba healing in the Kirpensteijn paper suggests that a minimum follow up of 1 month would be appropriate. Anecdotally, chronic incisional hernias can be noted weeks to years post-operatively (Smeak, 2012). On the human side,the European Hernia Society guidelines on the closure of abdominal wall incisions (in humans) (Muysoms et al., 2015) state that a 3 year follow-up should be mandatory in studies evaluating the rate of postoperative incisional hernia after midline laparotomy in humans.

Taken together, Rosin and Crowe provide weak evidence that a simple continuous pattern in the canine linea alba carries a low complication rate, with one major complication in 530 canine coeliotomy procedures (0.19\%) (large majority of cases followed for at least 8 weeks on owner-assessed basis). This is in line with findings in humans, where the recommendation is to use a slowly absorbable monofilament suture in a simple continuous single layer aponeurotic closure with a small bite technique $(5-8 \mathrm{~mm}$ fascial bites placed every $5 \mathrm{~mm}$ ) (Muysoms et al., 2015).

The quality of evidence available to answer this question was disappointing. There were very few randomised controlled studies and those identified had significant flaws in methodology and were lacking in power. The strength of evidence provided by case series studies is less than that provided by randomised controlled studies (Aragon et al., 2005). The three case series-based studies identified here had inherent major limitations that further compromised the strength of evidence they provided, the most common limitation being insufficient veterinary follow-up duration.

Factors other than suture pattern are likely to affect healing of the linea alba post-coeliotomy, including (but not limited to) patient variables such as age and co-morbid disease, indication for surgery and surgical technique. In addition, a suture material that will retain a sufficient percentage of its tensile strength for long enough to support fascial healing should be selected (Sanz et al., 1988) regardless of which suture pattern is chosen. Knot security has been shown to be affected by suture type, number of throws per knot and surgeon experience (Marturello et al., 2014) so these factors should all be considered when performing surgery.

There is certainly scope for well-planned and executed studies in this area. A prospective, randomised controlled study comparing two groups of healthy adult dogs matched for age, size and body condition score 
undergoing elective ovariohysterectomy would be helpful. A power calculation needs to be performed before the study starts to ensure the groups are an appropriate size. Midline coeliotomy is likely one of the most commonly performed procedures in small animal practice in the UK so an improved evidence base regarding closure technique would be valuable.

\section{Methodology Section}

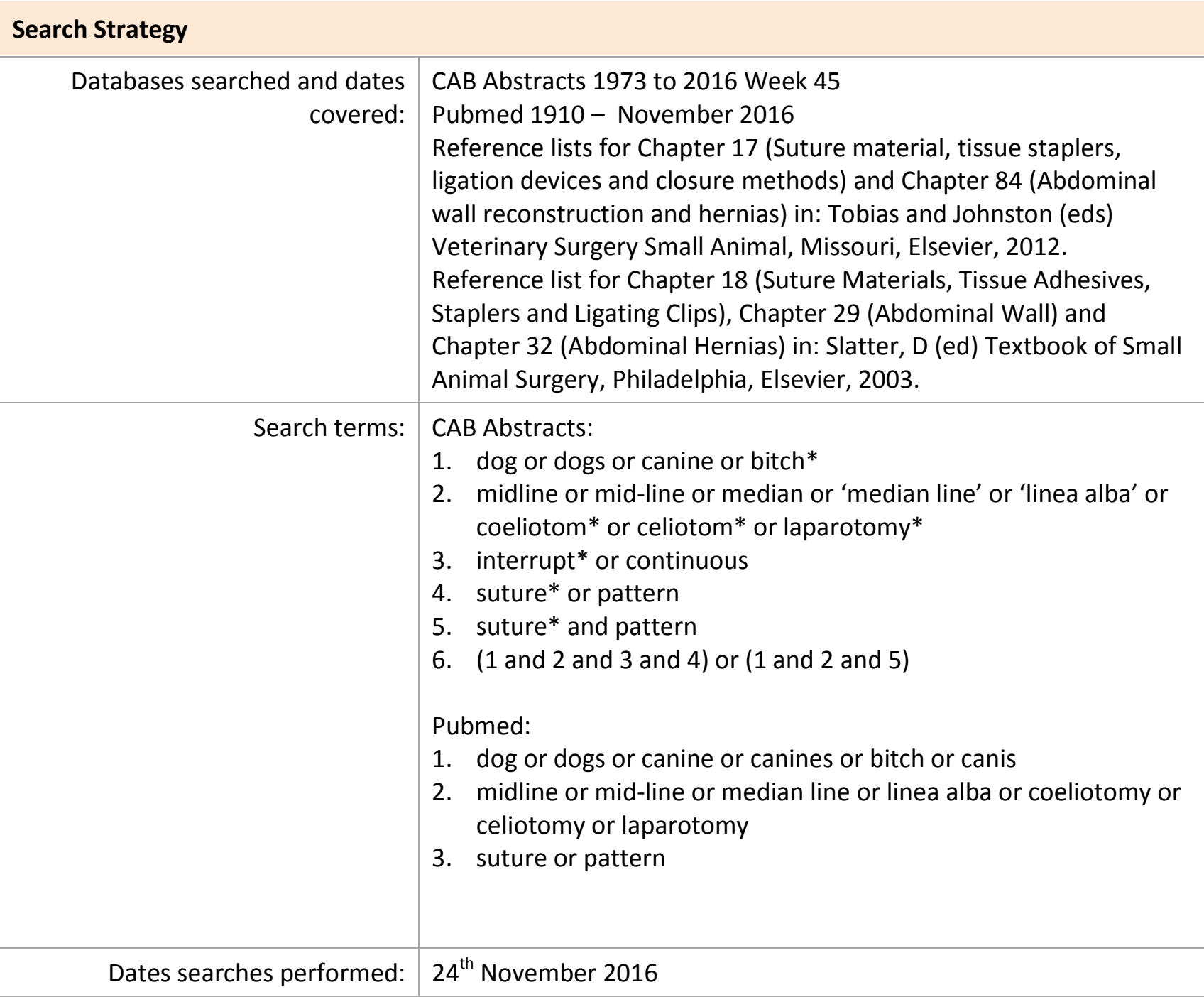

\section{Exclusion / Inclusion Criteria}

Exclusion: References written in a language other than English

Study on species other than dog

Title not relevant to PICO

Full text not relevant to PICO

Inclusion: Studies assessing healing of midline coeliotomy incisions in dogs where either a simple interrupted or simple continuous suture pattern was used for linea alba closure. 


\begin{tabular}{|c|c|c|c|c|c|}
\hline \multicolumn{6}{|c|}{ Search Outcome } \\
\hline Database & $\begin{array}{l}\text { Number of } \\
\text { results }\end{array}$ & $\begin{array}{l}\text { Excluded - Title } \\
\text { not relevant to } \\
\text { PICO }\end{array}$ & $\begin{array}{l}\text { Excluded - } \\
\text { species other } \\
\text { than canine }\end{array}$ & $\begin{array}{l}\text { Excluded - Paper } \\
\text { not relevant to } \\
\text { PICO on reading } \\
\text { full text }\end{array}$ & $\begin{array}{l}\text { Total } \\
\text { relevant } \\
\text { papers }\end{array}$ \\
\hline CAB & 25 & 22 & & & 3 \\
\hline Pubmed & 161 & 159 & & & 2 \\
\hline $\begin{array}{l}\text { Reference } \\
\text { list, Chapter } \\
\text { 17, Tobias } \\
\text { and Johnston }\end{array}$ & 164 & 163 & & & 1 \\
\hline $\begin{array}{l}\text { Reference } \\
\text { list, Chapter } \\
\text { 84, Tobias } \\
\text { and Johnston }\end{array}$ & 125 & 119 & 4 & & 2 \\
\hline $\begin{array}{l}\text { Reference } \\
\text { list, Chapter } \\
\text { 18, Slatter }\end{array}$ & 77 & 74 & 2 & & 1 \\
\hline $\begin{array}{l}\text { Reference } \\
\text { list, Chapter } \\
\text { 29, Slatter }\end{array}$ & 48 & 39 & 4 & 1 & 4 \\
\hline $\begin{array}{l}\text { Reference } \\
\text { list, Chapter } \\
\text { 32, Slatter }\end{array}$ & 86 & 81 & 3 & 1 & 1 \\
\hline Total relevant & pers whe & ved & & & 5 \\
\hline
\end{tabular}

\section{CONFLICT OF INTEREST}

The author declares that there was no conflict of interest in the preparation of this paper. 


\section{REFERENCES}

1. Aragon, C. and Budsberg, S. (2005). Applications of evidence-based medicine: cranial cruciate ligament injury repair in the dog. Veterinary Surgery, 34 pp. 93-8 http://dx.doi.org/10.1111/j.1532$\underline{950 X .2005 .00016 . x}$

2. Bellenger, C. (2003) Abdominal Wall. In Slatter: Textbook of Small Animal Surgery, 405-13.Crowe, D. (1978). Closure of abdominal incisions using a continuous polypropylene suture: clinical experience in 550 dogs and cats. Veterinary Surgery, 7 pp. 74-7.

3. Kennedy, K., Tamburello, K. and Hardie, R. (2011). Peri-operative morbidity associated with ovariohysterectomy performed as part of a third-year veterinary surgical training program. Journal of Veterinary Medical Education, 38 (4), pp. 408-13. http://dx.doi.org/10.3138/ivme.38.4.408

4. Kirpensteijn, J., Fingland, R., Boyer, J. et al. (1993). Comparison of stainless steel fascial staples and polypropylene suture material for closure of the linea alba in dogs. Veterinary Surgery, 22 (6), pp. 46472. http://dx.doi.org/10.1111/j.1532-950X.1993.tb00423.x

5. Kummeling, A. and van Sluijs, F. (1998). Closure of the rectus sheath with a continuous looped suture and the skin with staples in dogs: speed, safety and costs compared to closure of the rectus sheath with interrupted sutures and the skin with a continuous subdermal suture. The Veterinary Quarterly, 20 (4), 126-30. http://dx.doi.org/10.1080/01652176.1998.9694856

6. Marturello, D., McFadden, M., Bennett, A., et al. (2014). Knot security and tensile strength of suture materials. Veterinary Surgery, 43 (1), pp. 73-9. http://dx.doi.org/10.1111/j.1532-950X.2013.12076.x

7. Muysoms, F., Antoniou, S., Bury, K. et al. (2015). European Hernia Society guidelines on the closure of abdominal wall incisions. Hernia, 19 (1), 1-24. http://dx.doi.org/10.1007/s10029-014-1342-5

8. Rosin, E. (1985). Single layer, simple continuous suture pattern for closure of abdominal incisions. Journal of the American Animal Hospital Association, 21, 751-6.

9. Sanz, L., Patterson, J., Willet, G. et al. (1988) Comparison of Maxon suture with Vicryl, chromic catgut, and PDS sutures in fascial closures in rats. Obstetrics and Gynaecology 71, 418-22.

10. Smeak, D. (2012). Abdominal wall reconstruction and hernias. In Tobias and Johnston: Veterinary Surgery: Small Animal, 1353-79 


\section{Cinam \\ ochese}

\section{Intellectual Property Rights}

Authors of Knowledge Summaries submitted to RCVS Knowledge for publication will retain copyright in their work, and will be required to grant to RCVS Knowledge a non-exclusive license of the rights of copyright in the materials including but not limited to the right to publish, re-publish, transmit, sell, distribute and otherwise use the materials in all languages and all media throughout the world, and to license or permit others to do so.

\section{Disclaimer}

Knowledge Summaries are a peer-reviewed article type which aims to answer a clinical question based on the best available current evidence. It does not override the responsibility

of the practitioner. Informed decisions should be made by considering such factors as individual clinical expertise and judgement along with patient's circumstances and owners' values. Knowledge Summaries are a resource to help inform and any opinions expressed within the Knowledge Summaries are the author's own and do not necessarily reflect the view of the RCVS Knowledge.

Veterinary Evidence and EBVM Network are RCVS Knowledge initiatives. For more information please contact us at editor@veterinaryevidence.org

RCVS Knowledge is the independent charity associated with the Royal College of Veterinary Surgeons (RCVS). Our ambition is to become a global intermediary for evidence based veterinary knowledge by providing access to information

that is of immediate value to practicing veterinary professionals and directly contributes to evidence based clinical decision-making.

www.veterinaryevidence.org

RCVS Knowledge is a registered Charity No. 230886. Registered as a Company limited by guarantee in England and Wales No. 598443.

Registered Office:

Belgravia House

62-64 Horseferry Road

London SW1P 2AF 